\title{
IAMJ
}

INTERNATIONAL

AYURVEDIC

MEDICAL JOURNAL

Review Article

ISSN: 2320-5091

Impact Factor: 6.719

\section{SYSTEMATIC REVIEW ON UNDERSTANDING AND MANAGEMENT OF VATARAKTA: A REVIEW ARTICLE}

\author{
Vaibhavi Bhavar ${ }^{1}$, Atal Bihari Trivedi ${ }^{2}$ \\ ${ }^{1}$ MD Scholar, Department of Kayachikitsa, Chaudhary Brahm Prakash Ayurved Charak Samsthan, Najafgarh, \\ Khera Dabar, New Delhi, 110073. \\ ${ }^{2}$ Associate Professor, Department of Kayachikitsa, Chaudhary Brahm Prakash Ayurved Charak Samsthan, \\ Najafgarh, Khera Dabar, New Delhi, 110073
}

Corresponding Author: vaibhavibhavar01@gmail.com

\section{https://doi.org/10.46607/iamj1709102021}

(Published Online: October 2021)

Open Access

(C) International Ayurvedic Medical Journal, India 2021

Article Received: 04/09//2021 - Peer Reviewed: 24/09/2021 - Accepted for Publication: 27/09/2021

\section{Check for updates}

\section{ABSTRACT}

BACKGROUND: In today's modern period, the lifestyle of people has changed, food habits also has changed, it is going more towards sedimentary lifestyle. People nowadays preferred to have instant, junk, and spicy fast food than a normal healthy diet. Hence nowadays more and more people are developing so many metabolic disorders due to inactive, sluggish, seated lifestyles. Among so many metabolic disorders gout is the one that commonly occurs in today's modern manner of living. Purine metabolism causes hyperuricemia and deposition of monosodium urate crystals in joints. In Ayurveda, Vatarakta shows so much resemblance with gouty arthritis. Vatarakta is mainly an Avaranajanya Vata Pradhan Tridoshaja Vyadhi where Rakta is main Dushya.Vatarakta is more distressing. Due to the desk-bound lifestyle, many people are affected constantly by this severe disease. Currently, in modern science NSAIDS, allopurinol, colchicine, the corticosteroid is being used to treat gout. But these drugs have many adverse effects and disadvantages Panchkarma induced Shodhana and Shamana is not only an important component of Ayurvedic treatment but also the elemental basis of Ayurvedic treatment. Different procedures like Swedana, Vamana, Virechana, Basti, Raktamokshana focuses on purification which detoxifies the patient's body and thus helps in correcting metabolism at the molecular level. Hence the Panchkarma is a quirky approach in the management of Vatarakta. Shamana refers to all the Ayurvedic procedures and protocols that reduce suppress and eliminate the 
disease. Shamana Chikitsa is planned to make the patient recover and feel healthier by suppressing the disease symptoms. Hence while the inherent disease might still be present the patient going through Shamana Chikitsa can control the symptoms.

Keywords: Ayurveda, Cataract, Vata, Rakta, Gouty arthritis.

\section{INTRODUCTION}

The word Vatarakta is fabricated in two words Vata and Rakta. Where Vata is one of the three Doshas and Rakta is Dushya. The Ayurvedic text says Vata is more influential among Tridoshas due to its significant actions like regulation of movement, regulation of all activity of mind, initiation of natural urges1. The occurrence of Vatarakta is also possible when the Gati of Vata is obstructed by abnormal unhealthy vitiated Rakta Dhatu. Eating a food consist of salty, sour, hot, pungent, alkaline, greasy, and raw food, moist or dry things, the meat of submerged or marshy animals, sukta, buttermilk, sura, asav, consuming food during indigestion, anger, day-sleep, persons who eat flavoursome food for pleasure and is not in habit of walking, all these factors are Rakta Prakopaka 2. Food consisting of astringent, pungent, bitter, fasting, flourishing in water, hoping, jump over, excessive travelling on foot in the hot season, sexual intercourse, and suppression of urges thus aggravated Vata having been provoked in its passage by aggravated blood affects the entire blood.3 Due to the shiftiness of Vayu and liquidity and flowing Ness of blood it keeps moving all over the body through blood vessels. Being obstructed in joints due to the zigzag way it gets located there with agitation and in combination with pitta causes respective afflictions4. Hence it produces pain mostly in those very joints and the patient suffers from respective pain very hard to tolerate5 Characteristic of Vatarakta is Kandu [itching], Daha [burning sensation] Ruja [pain], Ayama [dilation of vessels], Toda [pricking pain] Sphurrana [throbbing sensation] Bhanjana [breaking bone-like pain]. Vatarakta affects feet with tenderness, pricking pain, tearing pain, excessive dryness, and numbness. The same, when associated with pitta and blood, have a severe burning sensation, excessive heat, red inflammation, and softness. If blood is vitiated by Kapha feet are white, cold, suffer from itching, swelling and become flabby and stiff.6 Vatarakta most commonly starts developing from the metatarsal phalangeal joint and pain develop gradually to other joints in the body. Hence Madhavnidana described it as Akhuvisham Evum Pida7 Vatarakta can be very well correlated with gout due to similar symptoms between them. The main cause of gout is sustained hyperuricemia. It may occur due to increased uric acid production or decreased uric acid elimination or amalgamation of both. Mean serum uric acid levels of more than $7 \mathrm{mgldl}$ in men and more than $6 \mathrm{mg} / \mathrm{dl}$ in women is said to be hyperuricemia8 Hyperuricaemia leads to formation and deposition of monosodium urate crystal which advantageously deposit in joint bursa, tendon, and spaces. The skin over the joint may subsequently desquamate. Manifestations include tenosynovitis, bursitis, cellulitis. The prevalence of hyperuricemia varies among societies. Most commonly occurs in men more than 40 years. The peak age for of onset of sustained Hyperuricemia in men is between 40 to 50 years. The use of Panchakarma therapy for the treatment of various ailments is increasing worldwide as they are considered much safer than synthetic drugs. Treatment of gout in modern medicine is the use of NSAIDs, colchicine, corticosteroids, to treat it symptomatically, so there is an urgent need for treatment from the Ayurvedic perspective drug in Vatarakta. In the present review, I have summarised various Panchakarma therapies for the management of Vatarakta.

\section{AIM AND OBJECTIVE:}

1. To review the available literature in Ayurvedic text and its correlation with modern literature on hyperuricemia.

2. To review Vatarakta in the context of gout

3. To review the management of Vatarakta 
MATERIAL AND METHODS: Vatarakta has been explained decoratively in Brihatrayi by Acharya Charak, Acharya Sushruta, Vagbhata. From the period of Charak beyond the disease, Vatarakta has been described as a separate disease. Aadhya Vata, Khudda Vata, Vata Balasa, Vata Shonita, Vatarakta are few synonyms of Vatarakta.

\section{MANAGEMENT OF VATARAKTA:}

In the management of Vatarakta, Initially, the patient should be purgated after unction with oily or rough purgatives. Repeated application of enema should also be done. Besides sprinkling, massage, ointment, and unction substances that do not cause burning red hot are recommended.9

\section{ROLE OF PANCHAKARMA THEREPY IN VATARAKTA (Gout)}

SNEHANA: Snehana destroys vitiated Vata, softens the body and removes retention of excrements. Fomentation (applied) to the unacted person liquifies the impurity hidden in minute channels. 10 Snehan divides into two administrations-External and internal. Sneha Dravya's like Ghee or Oil either medicated or non medicated are used. In Uttana Vatarakta external use of Snehana is mainly carried out. Abhyantar Snehan is mainly given in Gambheer Vatarakta and according to Koshtha, Dosha Bala, Agni Bala and Prakriti of patient-internal administration are decided.

SWEDANA: The process which relives Sheeta, Shoola, Stambha, Gaurav in the body is Swedana karma.

Fomentation (Swedana) will be described as a proper application by which the disease due to Vata and Kapha are amenable to fomentation and are alleviated. By application of fomentation before unction has been done, Vata is won over and thus faeces urine and semen are never obstructed. Fomentation is said as effective if applied with consideration of disease and season11 Usually Swedana is contraindicated in Vatarakta but usually in vitiated Vatadhika, Kaphadhika Vatarakta Mridu Swedana is Advised. It may be given in the form of warm application. Uttana Vatarakta should be treated with Alepana, Abhyanga, Parisheka and Upanaha Sweda12.Swedana procedure has an impact on Ushna guna, so it does Strotho Shudhhi and
Ama pachana. Gaurava, swayathu Ruja, Ayama are symptoms of Vatarakta which get relieved due to Swedana in Vatarakta.

VAMANA: In Samprapti of Vatarakta main involvement of Kapha and Vata is found which represents symptoms like itching, swelling, stiffness and hardness.13 The Ushna, Tikshna, Sukshma, Vyavayi and Vikasi Guna of Vamana Dravyas reaches the heart and circulates through vessels, the mass of impurity in the entire body liquefy it out through large and small ducts due to fiery nature and disjoin it due to sharpness, the disjoined mass floating in the vessels reaches the stomach due to penetrating nature and being propelled by Udana Vayu is thrown up because of the natural composition of the drugs with Agni and Vayu.14 In Vatarakta when there is a predominance of Kapha, mild emesis should be done.15 Thus Vamana karma directly acts Kapha, thereby checking Samprapti of Vatarakta.

VIRECHANA: After unction patient is purgated first with unctuous or rough mild purgatives. Frequent application of enema should be done. In Charak, it is mentioned that Gambhir Vatarakta should be treated with purgation16. Repeated Virechana should be carried as virechana is important in Shodhana Chikitsa.

BASTI: Basti is the most relevant procedure in Vatarakta.In Vatarakta Vata Dushti predominance is there. As Vayu Dosha is responsible for the Samprapti(pathogenesis) of Vatarakta. With their receptacles, there is no remedy other than Basti for pacification when it is aggravated severely. Hence enema is said as half medicine17 Niruha and Anuvasan basti both should be repeated simultaneously. There is no treatment of Vatarakta equal to enema.18

RAKTAMOKSHAN: Vatarakta is Raktapradoshaaj Vikara due to which Raktamokshana with the help of Shringa, Alabu, Pracchana, Siravedhhana according to Dosha and body would be preferred treatment. Vayu has obstructed the passage of blood, in such cases, blood should be let out with horn, leech, needle, bottle gourds or venesection according to strength. Blood should be taken out with leech from one suffering from distress, burning sensation, piercing pain and redness. One 
should take out blood from the patient having numbness, itching and prickly sensation with horns or bottle gourds. If the disorder is shifting from place to place, it should be eliminated by venesection. 19

\section{SHAMANA CHIKITSA: \\ GUGGULU}

\section{1)Kaishore Guggulu:20}

\section{Composition:}

Terminalia Chebula, Terminalia Bellirica, Phyllanthus Emblica, Tinospora Cordifolia, Commiphora Mukul, Zingiber Officinalis, Piper longum, Piper Nigrum, Emilia Ribes, Beliospermum Montanum, Operculina terpethum, Ghee.

\section{Indication:}

In Bhaishajya Ratnawali it is mentioned that it helps to cure Tridoshaja Vatarakta other than that it is also helpful in Kushta, Vrana, Gulma, Prameha pidika, Pramheha, Mandagni, Kasa, Shwasa, Pandu 21

Dose: 2-3 grams in divided doses with warm water.

2)Amrutadi Guggulu Dvitiya:22

\section{Composition:}

Tinospora Cordifolia, Terminalia Chebula, Terminalia Bellerica, Emblica officinale, Operculum terpenthum, Baliospermum montanum, Embelia ribes.

\section{Indication:}

In Bhaishajya Ratnawali it is mentioned that it helps to cure Vatarakta, Kushta, GudajaVyadh, Bhagandara, Dushta vrana, Prameha, Aamvata, Shwayathu.

Dose: 2-3 grams in divided doses with water.

\section{3) Yogaraj Guggulu:23}

\section{Composition:}

Plumbago Zeylanica, Long pepper root, Trachyspermum ammi, Piper Chaba, Trachyspermum roxburhianum, Cumin seed, Cedrous Deodara, Piper cubeba, Elettaria cardamomum, Rock salt, Saussurea Lappa, Pluchea Lanceodata, Tribulus Terrestris, Coriandrum sativum, Terminalia Chebula, Terminalia bellirica, Emblica officinalis, Cyprus Rotundus, Zingiber officinale, Piper longum, Piper Nigrum, Vetiveria Zizanioides,
Hordeum Vulgare, Abbies webbiana, Cinamomum zeylanicum, Commiphera mukul, Ghee.

\section{Indication:}

Adhyavata, Aamvata, Krimi Roga, Kushta Roga, Vrana, Pleeha roga, Gulma Roga, Vatavyadhi.

Dose: 2-3 grams daily in divided doses with warm water.

\section{4) ASAVA \\ 1) Chavikasava: 24 \\ Composition:}

Paper Chaba, Plumbago Zeylanica, Gardenia Gummifera, Inula Recemosa, Acorus Calamus, Juniperus Communis, Curcuma Zedoaria, Trichosanthes Dioica, Terminalia Chebula, Terminalia Bellirica, Emblica offcinalis, Trachyspermum ammi, Coriandrum sativum, Pluchea Lanceolata, Baliospermum Montanum, Embelia Ribes, Cyperus Rotundus, Rubia cordifolia, Zingiber officinale, Piper Nigrum

\section{Indication:}

Vatashonita, Gulma, Prameha, Pratishyaya, Kas, Ashthhila.

Dose: $15 \mathrm{ml}$ with equal water after food

2)Sarivadyasava: 25

\section{Composition:}

Hemidesmus indicus, Cyprus rotundus, Symplocos racemose, Ficus benghalensis, Ficus religiosa, Hedychium, Prunus cerasoides, Coleus vettiveroides, Cissampelos pareira, Emblica officinalis, Tinospora cordifolia, Vetiveria zizanoides, Santalum Album, Pterocarpus marsupium, Trachyspermum ammi, Picrorrhiza kurroa,

Cinnamomum tamala, Amomum subulatum, Elettaria caramomum, Saussurea lappa, Cassia angustifolia, Terminalia chebula, Woodfordia fruticose, Vitis vinifera.

\section{Indication:}

According to Bhaishya Ratnawali Sarivadyasawa is helpful in Vatarakta, Prameha, Pidika, Bhagandara, Updanshika Vyadhi.26

Dose: $15 \mathrm{ml}$ with equal water after food 


\section{GRITA}

\section{1)Shatadhauta Ghrita27}

A special but very simple ghee preparation of Shatadhauta Grita is used in many skin conditions like burning sensation for a soothing effect.

While treating Vatarakta symptoms are associated with Pitta and Vata, in such case, Shatadhauta Grita should be applied externally over the affecting skin for the soothing effect.

DOSE:6- 12 grams twice a day with warm milk or water empty stomach.

\section{2) Panchatikta Grita:28}

\section{Composition:}

Luffa acutangular, Azadiracta indica, Solanum xanthocarpum, Tinospora cordifolia, Adhatoda vasica, Terminalia chebula, Terminalia bellirica, Emblica officinalis Ghee.

\section{Indication:}

Panchatikta Ghrita helps to soothe the Vata, Pitta and Kapha. It helps to reduce vitiated Vata and Pitta, thus helping to reduce burning sensation, pain associated with Vatarakta.

DOSE: 6-12 grams twice a day with warm milk or water empty stomach.

\section{TAIL:}

\section{Guduchyadi Tail: 29}

Composition:

Tinospora Cordifolia, Vitis vinifera, Gmelina arborea, Glycyrrhiza glabra, Oil.

Indication: local application of Guduchyadi tail helps to cure symptoms of Vatarakta.

*For local application.

\section{Pinda Taila 30}

\section{Composition:}

Rubia cordifolia, Vateria indica, Hemidesmus indicus, Bee's wax, Oil.

Indication: Helps to cure Ruja in Vatarakta.

*For local application

\section{Khuddaka Taila}

\section{Composition:}

Prunus cerasoides, Vetiveria zizaniodes, Glycyrrhiza glabra, Curcuma longa, Vateria indica, Rubia cordifolia, Fritillaria roylei, Santalum album
Indication: Helps to cure Vatarakta and the burning sensation associated with it.

*For local application.

\section{DISCUSSION}

In this review article conceptual part of Vatarakta and its Shodhana and Shamana management associated with it has been described for better perception of Vatarakta and its treatment protocol. In Vatarakta main wrongdoer is Vata and Rakta.In Charak it has been described as 'Padayomulam Asthaya. In modern it is mainly characterised by pain at the metatarsophalangeal joint subjectively. Nutritional conduct and lifestyle sense modality plays the foremost role in the roots of Vatarakta. A protein-rich diet, salty diet, alcohol intake on regular basis increases purine metabolism which ultimately results in uric acid formation. The pathology of Margavarana chiefs founding of clinical signs and indications in Vatarakta. Additional to enhance Shodhana, ShamanaRasayana, Bahiparimarjana Chikitsa all are aimed at the renovation of this Avaranajanya disease.

\section{CONCLUSION}

In the current era due to a desk-bound lifestyle, Vatarakta is one of the common metabolic diseases in day-to-day practices. Thus, it is high time to find out the best solutions to treat this disease. It is big time to probe the role of and application of Ayurvedic drugs and therapies in Vatarakta. It is known that Raktamokshan provides sudden relief in symptoms like burning sensation and pain in Vatarakta. Yoga Basti gives better relief in symptoms of Vatarakta. Shamana Chikitsa acts as a primary mode of care. The approach of Shamana Chikitsa helps to enhance the overall health of the body. Ayurveda turning a better substitute day by day for the treatment of Vatarakta.

\section{REFERENCES}

1. Vaidya BHP, editors. Vagbhata, Ashtanga Hridaya, Shareera Sthana -Angavibhanga Adhyaya 3/84 9th 
edition. Varanasi: Chaukambha orientalia; 2002.page no. 402

2. Prof Priyavrat Sharma Editor-Translator.Caraka Samhita Chikitsa sthan Vatashonita Chikitsa adhyaya 29/6,7,8page no 487 published by Chaukhambha Orientalia varanasi

3. Prof Priyavrat Sharma Editor-Translator.Caraka Samhita Chikitsa sthan Vatashonita Chikitsa adhyaya 29/9,10 page no 487 published by Chaukhambha Orientalia varanasi

4. Prof Priyavrat Sharma Editor-Translator.Caraka Samhita Chikitsa sthan Vatashonita Chikitsa adhyaya 29/14,15 page no 487 published by Chaukhambha Orientalia varanasi

5. Prof Priyavrat Sharma Editor-Translator.Caraka Samhita Chikitsa sthan Vatashonita Chikitsa adhyaya 29/14,15 page no 487 published by Chaukhambha Orientalia varanasi

6. Edited and translated by prof Priya vat sharma Sushruta Samhita nidana sthana, vatavyadhi adhyaya 1/45,46 page no 11 published by Chaukhambha visvabharati oriental publishers and distributors

7. Madhavnidana Madhukosh Vidyotinitikadvayopetam nidansthana adhyaya vatarakta page no 503

8. J. Larry Jameson. Harrison's Principles of Internal Medicine, $20^{\text {th }}$ edition: Robert Harrison; 2018.page no2998

9. Prof Priyavrat Sharma Editor-Translator.Caraka Samhita Chikitsa sthan Vatashonita Chikitsa adhyaya 29/41 page no 490 published by Chaukhambha Orientalia varanasi

10. Prof Priyavrat Sharma Editor-Translator.Caraka Samhita Siddhi sthan kalpanasidhi adhyaya 1/7 page no 588 published by Chaukhambha Orientalia varanas

11. Prof Priyavrat Sharma Editor-Translator.Caraka Samhita Sutrasthan swedaadhyaya 14/3,5,6 page no 95 published by Chaukhambha Orientalia varanas

12. Prof Priyavrat Sharma Editor-Translator.Caraka Samhita Chikitsa sthan Vatashonita Chikitsa adhyaya 29/20,21 page no 488 published by Chaukhambha Orientalia varanasi

13. Prof Priyavrat Sharma Editor-Translator.Caraka Samhita Chikitsa sthan Vatashonita Chikitsa adhyaya 29/43 page no 490 published by Chaukhambha Orientalia varanasi

14. Prof Priyavrat Sharma Editor-Translator.Caraka Samhita Kalpasthanam madankalpa adhyaya $1 / 5$ page no 538 published by Chaukhambha Orientalia varanasi
15. Prof Priyavrat Sharma Editor-Translator.Caraka Samhita Chikitsa sthan Vatashonita Chikitsa adhyaya 29/46 page no 490 published by Chaukhambha Orientalia varanasi

16. Prof Priyavrat Sharma Editor-Translator.Caraka Samhita Chikitsa sthan Vatashonita Chikitsa adhyaya29/41 and 29/43 page no 490 published by Chaukhambha Orientalia varanasi

17. Prof Priyavrat Sharma Editor-Translator.Caraka Samhita siddhi sthana Kalpanasidhhi adhyaya 1/40 page no 588 published by Chaukhambha Orientalia varanasi

18. Prof Priyavrat Sharma Editor-Translator.Caraka Samhita Chikitsa sthan Vatashonita Chikitsa adhyaya 29/88 page no 494 published by Chaukhambha Orientalia varanasi

19. Prof Priyavrat Sharma Editor-Translator.Caraka Samhita siddhi sthana Kalpanasidhhi adhyaya 1/35,36,37 page no 489 published by Chaukhambha Orientalia varanasi

20. Edited by Bhisagratna Shri Brahmashankar Mishra Translator Dr Kanjiv Lochan Bhaishajyaratnawali Madhyama Khanda, Vatarakta Chikitsa prakarana 27/108 page no 257 Published by Chaukhamba Sanskrit Sansthan

21. Sharangdhara Samhita Madhyama Khanda 7/70-81

22. Edited by Bhisagratna Shri Brahmashankar Mishra Translator Dr Kanjiv Lochan Bhaishajyaratnawali Madhyama Khanda, Vatarakta Chikitsa prakarana 27/119 page no 260 Published by Chaukhamba Sanskrit Sansthan

23. Edited by Bhisagratna Shri Brahmashankar Mishra Translator Dr Kanjiv Lochan Bhaishajyaratnawali Madhyama Khanda, Vatarakta Chikitsa prakarana 29/160 page no 550 Published by Chaukhamba Sanskrit Sansthan

24. Edited by Sri Gangasahaya pandeya, Shri Vaidya Sodhala with the vidyotini Hindi commentary by Shri Indradeva Tripathi Gadanigraha Prayoga khanda part 1 Asavaadhikara shashtha Gulme Chavikasava 6/195 page no 378 published by Chaukhamba Sanskrit sansthan Varanasi

25. Edited by Bhisagratna Shri Brahmashankar Mishra Translator Dr Kanjiv Lochan Bhaishajyaratnawali Madhyama Khanda, Vatarakta Chikitsa prakarana 38/27 page no 311 Published by Chaukhamba Sanskrit Sansthan

26. Govinda Dasji Bhishagratna commented upon by Vaidya Shri Ambica Datta Shastri, English translation by Dr. Kanjiv Lochan Bhaishajya ratnawali, 
Pramehapidikachikitsa Prakaran 38/27 page no 550 Published by Chaukhamba Sanskrit sansthan Varanasi.

27. Editorial board Rajeswardatta sastri, Yadunandana Upadhyaya, Ganga sahaya pandeya, Banarasidasa gupta. Translator Caraka Samhita Sharira Sthana Jatisutriya Sharira Adhyaya 8/24-page no.931 published by Chaukhamba Bharati Acadamy

28. Edited by Bhisagratna Shri Brahmashankar Mishra Translator Dr Kanjiv Lochan Bhaishajyaratnawali Volume 3, Kushtaprakarana 54/259-page no82 Published by Chaukhamba Sanskrit Sansthan

29. DrGangasahaya PandeyaA.M.S. forwarded by Vaidya Yadavji Trikami Acharya, Caraka Samhita Chikitsa Sthana Vatashonita adhyaya 29/121 page no 744 published by Chaukhamba Sanskrit Sansthan.Varanasi.

30. DrGangasahaya PandeyaA.M.S. forwarded by Vaidya Yadavji Trikami Acharya, Caraka Samhita Chikitsa Sthana Vatashonita adhyaya $29 / 123$ page no 745,29/114vpage no 744 published by Chaukhamba Sanskrit Sansthan. Varanasi.

\section{Source of Support: Nil Conflict of Interest: None Declared}

How to cite this URL: Vaibhavi Bhavar \& Atal Bihari Trivedi: Systematic Review On Understanding And Management Of Vatarakta: A Review Article. International Ayurvedic Medical Journal \{online\} 2021 \{cited October 2021\} Available from: http://www.iamj.in/posts/images/upload/2404_2410.pdf 